\title{
Compete or Cooperate: Understanding of the Relationship Levels of Firms within same Industry
}

\author{
Fahim Shaker \\ Lecturer, School of Business Studies, Southeast University, Dhaka, BANGLADESH
}

\begin{abstract}
This paper tries to address various dimensions of the firm relationship that are competing in the same industry. Competitive strategies play important role for a firm's survival and to achieve sustainable competitive advantage. However, firms can also decide to cooperate with each other through mobilization of resources to ensure mutual benefit and thus promote healthy competition. A strategic dilemma may occur for competing firms to cooperate with other who traditionally believe in competition, profit orientation, and self-interest. This paper tries to address firm level responses and interactions amongst each other in various consequences by relying on exploratory method of research. Firms competing in the same industry may opt for four different strategic options named as, competition, cooperation, coexistence and coopetition. Through the literature review, different forms of firm level relationships are explained under these four strategic options. This paper argues that cooperation is beneficial and may complement healthy competition amongst competing firms.
\end{abstract}

Keywords: Cooperation, Competition, Strategy, Competitive advantage JEL Classification Code: L10, L14

\section{INTRODUCTION}

Competitor analysis plays a significant role in gaining sustained competitive advantage as suggested by Michael Porter (1980) in his book 'competitive strategy'. Porter (1980) suggested a framework of generic strategies that may support a firm to outperform competitions and gain competitive advantage. Porter (1980) also suggested that in emerging markets, firms may face the strategic dilemma of choosing between competition and cooperation. In emerging markets, firms may need to pursue industry advocacy more in the form of cooperation while putting less emphasis on their narrowed 'self-interest'. In other words, firms may choose to cooperate with each other instead of competing in emerging markets which Porter (1980) described as a strategic dilemma. Contrary to this, scholars (Ven \& Garud, 1987) have argued that both competition and cooperation may exist amongst firms in an industry as a normal state of affair. Firms may not have to choose between competition and cooperation in order to gain competitive advantage in the market, they can both compete and cooperate simultaneously. An over emphasis on competition can actually distort a firm's sustainable competitive advantage (Harfield, 1999). Therefore, firms may also need to explore inter-firm relationship with each other in the form of cooperation to ensure industry growth. Barnett (2006) argued that, firms need to form collective strategy through collaboration and mobilization of resources in order to tackle environmental pressures as "there is strategic strength in numbers" (Barnett, 2006: 272). However, many firms do not radically change their individualized approach to a more collective approach typically due to their profit concern, managerial control, and discretion. The change of approach towards being collectivist requires firms to establish a working balance between individualized and collectivist approach. Strategists from the firms are required to address the issue of balancing between collectivist and individualized actions in order to remain competitive.

Different dimensions of inter-firm relationship are needed to be addressed to explain better how firms compete and cooperate with each other in an industry. The current paper, therefore, tries to provide a theoretical explanation to address various forms of the firm relationship which may be helpful to illustrate the critical balance between individual and collective action.

\section{ObJective OF THE Study}

The major idea of this paper is to address different dimensions of the firm relationship observed amongst competing firms under different consequences. To what extent a firm would interact with each other is an important issue to address within social network research? There had been many discussions regarding the importance of connectivity amongst the firms through maintaining cooperative networks to captivate individual interest with the exchange of resources amongst each other. However, to what extent, the firms would sacrifice individual benefits over mutual benefits is an important issue to address. Therefore, through this paper, I would like to address the different layers of 
relationships within competing firms influenced by different modes of consequences.

Geographic locations, the scope and nature of the industry, the number of struggling firms, and the level of political interventions are some of the key factors deciding the level of cooperation amongst the firms. According to Easton and Araujo (1992), there are four different types of relationships can be developed amongst the firms explained as, competition, coexistence, cooperation, and coopetition. Throughout the paper, the theoretical framework of these relationship levels amongst competing firms will be discussed within the context of literature.

\section{Methodology}

The paper tries to highlight the studies within the field of strategic management featuring competition and cooperation amongst business organizations. An exploratory research method is adopted to find out the relevant articles to address the firm's relationship level in various consequences. The study is compiled through secondary sources of data such as online journals and publications. The study is mostly concentrated towards the field of strategic management and social network research. The references are provided in the end section of the paper.

\section{SignificANCE OF THE STUdY}

This paper can be ideally significant to address the firm level interaction under different consequences. Traditionally, it is understood that firms need to remain competitive in order to sustain in the market. However, to remain competitive in the market, firms may address different circumstances by choosing to cooperate, coexist or even compete and cooperate simultaneously. The study may be significant to theoretically address these dimensions by highlighting the possible interaction levels amongst competing firms in various forms of competition. It may provide a platform for empirical evidence to address the core determinants that influence the firms within the same industry to adopt competition or cooperation.

\section{Literature Review}

From the definition of economics, we know that resources are scarce, and the best way to utilize scarce resources is to explore alternative uses of scarce resources. According to Robbins (1935:16), "Economics is a science which studies human behavior as a relationship between ends and scarce means which have alternative uses". Resources are limited while the desire for the produced goods is unlimited. Therefore, consumers decide upon the allocation of scarce resources to maximize the satisfaction defined as rational choice. According to the theories of rationality, "Rational individuals choose the alternative that is likely to give them the greatest
satisfaction"(Heath 1976: 3). From firm level perspective, this is important to decide upon the appropriate use of scarce resources in such ways so that it can ensure maximized profitability. Because of the limitation of resources, firms do interact with each other to develop a process with which the best methods can be discovered to exploit these resources to ensure mutual benefits. (Håkansson, et al. 2009). In other words, mobilization of resources is required to adopt cooperation and ensure mutual benefits. In the following sections, the way firms do interact with each other's described in four parts competition, coexistence, cooperation, and coopetition.

\section{Firms Chose to Compete}

The business worlds where firms do compete or cooperate with each other are defined as either 'jungle or 'metaphors' by Håkansson (et al. 2009). The business world in the mid-eighteenth century was categorized as 'jungle' like metaphor with intense rivalry and limited space for firms to interact and share resource with each other's (Håkansson et al. 2009). On the other hand, today's business world is more like 'rainforest' where inner-dependence is more important than independence and firms revitalize their resources through the process of interaction to ensure a satisfying level of profitability. (Håkansson et al. 2009). However, the rainforest approach rejects the contemporary theory of competition. According to rainforest approach, firms would try to outperform each other's by achieving sustainable competitive advantage through cost leadership or differentiation, a method of hybrid strategy ( Hitt, Ireland \& Hoskisson, 2009) . It may be contrasting to the viewpoint of economic 'theory of maximizing utility', (Marshall, 1920). The rainforest approach described by Håkansson et al, (2009) stresses out the importance of being a moderate risk taker in the market. Here, firms would try to maintain network amongst each other, create space for interaction, and ensure mutual benefits, something like a piece of cake for everyone. (Håkansson et al. 2009).

Therefore, the concern of rational choice amongst individuals is much dependent on the way the individuals interact with each other. Elster (1989) described-" The elementary unit of social life is the individual human action to explain social institutions and social change is to show how they arise as the result of the action and interaction of individuals" (Elster 1989: 13). Schneider (1974; cited in Granovetter, 1985: 482) criticized in the fact that "economic behavior was sufficiently independent of social relations for standard neoclassical analysis to be useful". Most of the sociologists had chosen the simplest path to analyze economic behavior without inclusion of complex sociological phenomena, a drawback according to Granovetter (1985).

Two ideal scenarios can be described here to explain the relationship level within competing firms to the context 
of social network approach. The first scenario is 'high rivalry' amongst the firms where each of the firms has sustainable competitive advantage to outperform each other. The interactions in such case scenarios are based on indirect relationships when buyer or seller connects the competitor to each other. (Granovetter, 1973). Though there is no realistic evidence of economic exchange in such situations, exchange of information and other forms of social activities take place. In intensely competitive industry, the competitors are linked to each other, according to their relative positions. (Easton \& Araujo, 1992). However, the competitors are not linked to each other's through the process of economic exchange. The firms would try to formulate a healthy social relationship for the purpose of 'getting to know your rival more'. This is not uncommon due to fact that in rapidly changing business environment, firms need to be more interactive to understand and evaluate each other's strength \& weakness. Needless to say, one firm's weakness can be perceived as other's opportunities, and such weaknesses can be explored through the maintenance of professional social network. Therefore, the organizations require sharp and high self- monitored individuals (Kilduff \& Tsai, 2003) to maintain a wide range of associations within the industry to receive updated information about the industry news and trends. Therefore, the importance of maintaining a network also plays a crucial role even in the case of highly competitive industry. This is also explained by scholars - "Social networks in organizations tend to be based on hierarchy, density, embeddedness"(Kilduff \& Tsai, 2003:87) and so on. With the development of sophisticated methods of operation, the complexity within the workforce is so apparent now days that, it requires dynamic adaption of the individuals within the organization. Therefore, firms are not only engaged in the production; but they are also engaged in strategic planning, internationalization, $\mathrm{R} \& \mathrm{D}$, and competitive strategies. There exists the need for a social network in which organizations tend to interact with each other through knowledge sharing, experience and innovation (Hansen, 2002). The existence of social network within an industry would enhance the inter-organizational boundary, promote tacit and explicit knowledge sharing, skill transfer, new product innovation and may also help to resolve various conflicts amongst competing firms.

\section{Firms Chose to Coexist}

The term coexistence of firms is not very much used in the literature of competition amongst firms. In his book 'Relationship among competitors', Easton (1990) discussed coexistence of firms along with four other forms (competitions, cooperation, conflict, collusion) of relationships between competitors. According to Easton, (1990) coexistence exists when the competing firms are said to be independent in term of their perceived goals.
From the perspective of the author, the competing firms merely challenge each other's when their goals do not mutually collide.

As discussed by Bengtsson and Kock (1999), social bonds between coexisting firms are omnipresent due to the familiarity of the firms to each other's influenced by a high level of informal reciprocal trust. Stipulated by individual goals, firms chose not to interfere with each other in case of competitive actions yet the firms have a considerable amount of dependence upon each other. It is because, firms in case of coexistence share information amongst each other's which are mutually beneficial. In other words, competitors are forced to maintain an association with each other for their individual interests, even though there is no existence of economic exchange. However, competitors strive for as little interactions as possible which gives rise to the relationship of coexistence, in which competitors know about each other, but do not challenge themselves. In this case, competitors are more like complementary partners with democratic niches for their operations. It happens when there are no conflicting positions amongst competitors and everyone's happy with their piece of cake. However, conflicting situations arise if one of the firms position is threatened by other or one of the firms foresees an opportunity to expand their business into the competitor's domain (Bengtsson and Kock, 1999).

\section{Firms Chose to Cooperate}

The most appropriate form of relationship amongst competitors is cooperation that is quite visible in most of the industries. According to Hunt (1996), some cooperation can enhance competition rather than thwart it. Cooperation amongst firms can be built based on the formal or informal characteristics of activities and distribution of resources among them. The cooperative form of interaction is the most important and demanding one amongst all sort of relationship layers amongst firms, and it is applicable to many industries where firm's activities are inner -dependent on each other. Firms do operate with the access to each other's resources, information, and knowledge sharing for collective achievement of mutual goals (Håkansso et al. 2009). The most constructive form of cooperation is interaction. According to Håkansson (et al. 2009: 47), "cooperation can be used to create and develop human and physical resources by exploiting time, it can initiate new process and give them particular direction over time". Here, according to the authors, cooperation in the form of interactions amongst firms can be utilized to incorporate with time and space to achieve mutual benefits. According to Håkansson (et al. 2009:54), "Interaction provides the possibility of taking advantage of the non-linear effects and creating new resource combination based on how specific measures are considered". It can be explained that the resources perceived as poor quality or unimportant, 
can have quite a huge significance when combined with other firm's resources, and can provide sufficient advantage, in the long run. Interaction is also helpful for competing firms across geographical areas, to "take advantage of unique place -related features of the business processes of purchase and supply" (Håkansson, et al. 2009:54). However, cooperation can be quite stressful and has its own set of drawbacks. Cooperation can be quite ineffective if individual benefits take place over mutual benefits, in the form of conflict of interest. (Bengtsson \& Kock, 2003).

However, the most important issues to address at the relationship level of competing firms are the choice of cooperation or competitions. Empirical evidences show that, firms would decide whether to compete or cooperate. based on the consequences described as 'activity' and 'resource' by Håkansson (et al. 2009). Firms can actively cooperate with each other in a specific activity or actively compete in another activity. The level of cooperation amongst firms would be decided by the capability of their resources. Typically, the lack of resource or inability to access some resources force firms to engage in cooperation with other in order to produce problem solutions. According to Richardson (1972), these activities are either complementary or similar to each other. If firms have unique capabilities to compete, they would rather choose competition instead of cooperation. Therefore, the basis for cooperation or competition varied between different types of activities and needed to be addressed in the social networking theories.

\section{Firms Chose to Compete and Cooperate Simultaneously Coopetition \\ Coopetition occurred when firms chose to compete and} cooperate simultaneously. (Bengtsson and Kock, 2000). The authors described coopetition as a form of relationship that can form intra-organizational, interorganizational or individual levels (Tsai, 2002; Bengtsson and Kock, 2000; Tidström, 2014). Coopetition is divided into vertical and horizontal levels. Vertical coopetition occurs between buyers and sellers while horizontal coopetition takes place between competitors.

When it comes to the proposition of firms deciding whether to compete or cooperate, firms are viewed as a rival or a partner. However, when it comes to the coopetition, firms are viewed as both rival and partner. It is, however a complicated discussion since Nalebuff and Brandenburger (1996) argued about coopetition being adopted by firms who are not competing in the same industry. However, a simplified argument would be to consider coopetition as the process of simultaneous competition and cooperation of firms belonging to the same industry and serving same or similar type of products ( Bengtsson and Kock, 2000; Laine, 2002). In the case of activities very closely directed towards customers, firms decide to compete with each other.
However, the same firms may decide to cooperate with each other in case of purchasing, service or some other activities not directly centered towards customers.

\section{Concluding Remarks}

From the above literature review, we discover the existence of cooperativeness and competitiveness in organizations. We can understand from the literature that, eventually no firm can operate under isolation. Even in a extremely competitive industry, firms need to interact with each other's having sustained competitive advantage. Cooperation and competition are two complementary terms in that sense since competition is being observed in industries where firms are highly cooperative and interactive to each other. Therefore, the extent to which a firm would cooperate or compete with other firms is highly dependent on various factors. These factors can be described as, the nature and scope of the work, functionality of the whole system, geographic locations, and so forth. For instance, a new firm needs to cooperate with existing firms to use and establish a brand name. On the other hand, existing firms may need to cooperate with the new firm to achieve a competitive advantage over other. It would be interesting to explore the undiscovered factors or determinants that make the firms decide about cooperation or competition. This can serve as a complementary study within the context of social networking theories.

\section{REFERENCES}

Awan, A. (2015). Shifting Global Economic Paradigm. Asian Business Review, 4(3), 35-40. Retrieved from http://journals.abc.us.org/index.php/abr/article/view/Ghafoor

Barnett, Michael L. (2006) Waves of collectivizing: A dynamic model of competition and cooperation over the life of an industry. Corporate Reputation Review, 8 (4). pp. 272-292.

Bengtsson, M. \& Kock, S. (1999): Cooperation and Competition in Relationships Between Competitors in Business Networks. Journal of Business and Industrial Marketing, Vol. 14, No. 3,178-194

Bengtsson, Maria and Kock, Sören (2000): Coopetitive Relationships in Business Networks - to Cooperate and Compete Simultaneously. Industrial Marketing Management

Bengtsson, Maria and Kock, Sören (2003): Tension in Coopetition. Paper presented at the 2003 Academy of Marketing Science Annual Conference, May 28-31. Washington D.C.

Charumbira, L. (2015). Strategic Management in Zimbabwean Profit and Non-profit Organizations: Identifying the Missing Tools in the Strategy Implementation Kit Bag. Asian Business Review, 4(3), 7.13. Retrieved from http://journals.abc.us.org/index.php/abr/article/view/Lysias

Chowdhury, A., Chowdhury, M., \& Imran, M. (2015). Branding strategies for service firms- a study on the selected Internet Service Providers (ISPs) in Bangladesh. Asian Business Review, 2(1), 47-53. Retrieved from http://journals.abc.us.org/index.php/abr/article/view/3 .8Chowdhury 
Chowdhury, M., \& Rahman, M. (2015). Consumer Attitude Towards the Cell Phone: A study on Young Generations of Chittagong Metropolitan City, Bangladesh. Asian Business Review, 3(3), 16-20. Retrieved from http://journals.abc.us.org/index.php/abr/article/view /5 .2Chowdhury

Easton, G. (1990), Relationships among competitors, In: The interface of marketing and strategy, ed. by Day, G., Weitz, B. and Wensley, R. London: JAI Pres Inc

Easton, Geoff \& Araujo, Luis (1992) Non-economic exchange in industrial networks in Industrial Networks- A New View of Reality Axelsson, B. \& Easton, G. (eds) Routledge, London

Elster, J. 1989. Nuts and Bolts for the Social Sciences. Cambridge: Cambridge University Press.

Fatema, M., Azad, M., \& Masum, A. (2015). Impact of Brand Image and Brand Loyalty in Measuring Brand Equity of Islami Bank Bangladesh Ltd.. Asian Business Review, 2(1), 42-46. Retrieved from http://journals.abc.us.org/index.php/abr/article/view/Fatema

Ferdous, M., \& Moniruzzaman, M. (2015). An Empirical Evidence of Corporate Social Responsibility by Banking Sector based on Bangladesh. Asian Business Review, 3(4), 82$87 . \quad$ Retrieved from http://journals.abc.us.org/index.php/abr/article/view/Ferdous

Granovetter, Mark (1973) "The Strength of Weak Ties", the American Journal of Sociology, 78, 6: 1360-1380

Granovetter, Mark (1985) "Economic Action and Social Structure: The Problem of Embeddedness", the American Journal of Sociology, 91, 3: 481-510

Håkansson, H., Ford, D., Gadde, L-E., Snehota, I. \& Waluszewski, A. (2009) Business in Networks. United Kingdom: John Wiley \& Sons Ltd.

Hansen, Morten T. (2002) " Knowledge Networks: Explaining Effective Knowledge Sharing in Multiunit Companies". Organization Science, Vol. 13, No. 3, Knowledge, Knowing, and Organizations. (May - Jun., 2002), pp. 232-248.

Harfield, T. (1999), Competition and cooperation in an emerging industry. Strat. Change, 8: 227-234.

Heath, A. 1976. Rational Choice and Social Exchange. Cambridge: Cambridge University Press.

Hitt, Michael A, Ireland, Duane R, \& Hoskisson, Robert E . (2009) " Strategic management: competitiveness and globalization: concepts \& case" South-Western College Pub; 8th edition

Hunt, Shelby D. (1996): Competing Through Relationships: Grounding Relationship Marketing in Resource-Advantage Theory. Paper presented at the Fourth International Colloquium on Relationship Marketing, September 23-24, Helsinki.

Kilduff, Martin \& Tsai Wenpin (2003) Social Networks and Organizations. Sage: London (172 pages).
Kilduff, Martin \& Tsai Wenpin (2003), Social Networks and Organizations. Sage: London

Laine, A.(2002), "Hand in Hand with the Enemy-Defining a Competitor from a New Perspective" The European Academy of Management,2nd Annual Conference on Innovative Research in Management, Stockholm, Sweden

Li, Z., \& Jiang, J. (2014). Problems and Strategies of Crossborder Mergers and Acquisitions for Chinese Enterprises. ABC Journal Of Advanced Research, 3(1), 29-33. Retrieved

from http://journals.abc.us.org/index.php/abcjar/article/view/5.4

Marshall, Alfred. (1920), Principles of Economics. An introductory Volume. 8th edition. London: Macmillan.

Nalebuff, Barry; Brandenburger, Adam M. (1996). Co-coopetition: a revolution mindset that combines competition and cooperation... the game theory strategy that's changing the game of business. New York, NY: Doubleday.

Porter, M. (1980). Competitive Strategy: Techniques for Analyzing Industries and Competitors, Free Press, New York

Qamruzzaman, M., \& Ferdaous, J. (2015). Building a Knowledge-Based Economy in Bangladesh. Asian Business Review, 4(3), 41-49. Retrieved from http://journals.abc.us.org/index.php/abr/article/vi ew/Qamruzzaman

Rahim, S., \& Tuli, F. (2015). The Effectiveness of Communication Practices with the Customers: A Comparative Study between Eastern Bank Limited and Mutual Trust Bank Limited. Asian Business Review, 3(3), 31$39 . \quad$ Retrieved from http://journals.abc.us.org/index.php/abr/article/view/Rahim

Rahman, S., \& Masoom, M. (2015). Effects of Relationship Marketing on Customer Retention and Competitive Advantage: A Case Study on Grameen Phone Ltd.. Asian Business Review, 1(2), 97-102. Retrieved from http://journals.abc.us.org/index.php/abr/article/view/2 .2Rahman

Richardson, G. B. (1972): The Organizing of Industry. The Economic Journal, Sept., pp. 883-896.

Robbins, L. (1935) the Nature and Significance of Economic Science (2nd ed.; Macmillan \& Co.), p. 16

Tidström, A. (2014). Managing tensions in coopetition. Industrial Marketing Management, 43 (2), 261-271.

Tsai, W. 2002., "Social structure of coopetition within a multiunit organization: Coordination, competition, and intra-organizational knowledge sharing. ", Organization Science, , 13, 179-190

Van de Ven, H. and Garud, R. (1987). A framework for understanding the emergence of new industries. Research on Technological Innovation, Management and Policy, 4, pp. 195 \pm 225

$$
\text { -- } 0 \text {-- }
$$

